GUZMÁN, José Luis "Sentido de la pena y reparación”.

Polít. crim. Vol. 12, № 24 (Diciembre 2017), Art. 10, pp. 1044-1065.

[http://www.politicacriminal.cl/Vol_12/n_24/Vol12N24A10.pdf]

\title{
Sentido de la pena y reparación
}

\section{The meaning of the penalty and of the reparation}

\author{
José Luis Guzmán Dalbora*
}

\section{Resumen}

El sentido de la pena no es igual a la llamada finalidad de la pena. Los fines de la pena son arbitrarios. El sentido de la pena halla un fundamento valorativo en la idea del Derecho. Sin embargo, justicia, seguridad jurídica y utilidad no pueden brindar una justificación apropiada a la pena. Su sentido lo adquiere la pena de la idea de la humanidad. La humanidad lleva desde la retribución del delito a la reparación del daño causado por el delito. Y la reparación conduce a reconstruir en muchos aspectos la Parte general del Derecho penal.

Palabras clave: Sentido y fin de la pena, justicia, seguridad, utilidad, retribución, reparación.

\begin{abstract}
The meaning of the penalty is not equal to the so-called purpose of the penalty. The meaning of the penalty finds an evaluative foundation in the idea of the Law. However, justice, legal certainty (security) and utility cannot provide an appropriate justification for the penalty; it acquires its meaning from the idea of humanity. Humanity goes from the retribution of the crime to the reparation of the damage caused by the crime. And the reparation leads to rebuilding in many respects the general part (general Theory) of Criminal law.
\end{abstract}

Key words: Meaning and purpose of penalty, justice, security, utility, retribution, reparation.

\footnotetext{
* Profesor titular de Derecho penal y de Introducción a la Filosofía moral y jurídica en la Universidad de Valparaíso (Chile). Miembro de la Fundación Internacional Penal y Penitenciaria. Director del Instituto de Ciencias Penales de Chile. Miembro investigador del Centro de Investigaciones de Filosofía del Derecho y Derecho penal de la Universidad de Valparaíso. Correo electrónico: joseluis.guzman@uv.cl

Este trabajo, que el autor expuso en el XXII Seminario Internacional del Instituto Brasileño de Ciencias Criminales, realizado en la ciudad de São Paulo los días 23 a 26 de agosto de 2016, reproduce y profundiza ideas desarrolladas en su libro Elementi di Filosofia giuridico-penale, edición al cuidado de Gabriele Fornasari y Alessandra Macillo, Editoriale Scientifica, Napoli, 2015. Agradezco especialmente las valiosas observaciones teóricas y sugerencias bibliográficas que me formularon los doctorandos Juan Pablo Castillo Morales (Universidad de Trento) y Diego Antonio González Lillo (Universidad de Barcelona).
} 
GUZMÁN, José Luis "Sentido de la pena y reparación”.

\section{Introducción: Delimitación conceptual y enclave axiológico del tema.}

La Filosofía jurídico-penal puede ser definida como la consideración abstracta y omnicomprensiva del Derecho penal, en otras palabras, como el conjunto de doctrinas generales que se puede proclamar en el campo punitivo con un carácter absoluto. Sus temas son los mismos que interesan a la Filosofía del Derecho en general, sólo que ceñidos a su presentación criminalista. Ellos son los siguientes: $1^{\circ}$ ) el fundamento o justificación (el por qué) del ius puniendi. En sus dos dimensiones, o sea, como fundamento ideal y fundamento real, estamos ante una parte, acaso la más significativa, de la razón de ser del Derecho en su papel de ordenamiento regulador de la conducta; $2^{\circ}$ ) los elementos universales y conceptos necesarios de este sector del ordenamiento, así como los principios que lo constituyen e informan, pareja de asuntos que deriva de los conceptos y principios jurídicos fundamentales, y que requiere afrontar la índole y las relaciones del Derecho penal dentro del árbol jurídico; $3^{\circ}$ ) las disciplinas criminales, es decir, los saberes a que corresponde ocuparse de delito y pena, con sus respectivos métodos y conexiones lógicas; en este aspecto, la Filosofía jurídico-penal es enciclopedia de las ciencias criminales ${ }^{1}$, y $4^{\text {o }}$ ) el sentido de la pena, capítulo que pertenece en iguales proporciones a los conceptos jurídicos fundamentales y la idea del Derecho en general.

El concepto del Derecho penal pertenece a la Filosofía jurídica en cuanto representa una parte o flexión del concepto lógico-abstracto del Derecho en su conjunto. A su turno, el concepto del delito desarrolla el concepto jurídico fundamental de la antijuridicidad en una cuestión de grado, culminando en la precisión que le confiere su diferencia específica al interior de los actos injustos, la punibilidad. El concepto de la pena es desplegado a partir de la punibilidad, aunque también entronca con la naturaleza garantizadora y el carácter secundario del Derecho penal, como la especie de sanción jurídica de carácter público que el respectivo ordenamiento considera de mayor gravedad.

Las tres investigaciones precedentes, de índole conceptual, se integran en la primerísima e inicial tarea de la Filosofía jurídico-punitiva, esto es, la definición de esta rama del Derecho y la determinación de sus elementos universales. Ninguno de los miembros de la tríada se substrae a una referencia a valores. El Derecho penal, porque sus proposiciones asocian penas a la infracción de normas de cultura, fines valorados por las comunidades nacional o internacional; el delito, porque su especial gravedad le viene dada de que atenta contra los bienes de mayor importancia para la organización social respectiva, según las valoraciones dominantes en ella; en fin, la pena, porque su distinción de las restantes sanciones jurídicas, en particular las disciplinarias y administrativas, es de corte cuantitativo, vista la gravedad que le asigna el ordenamiento a la luz de los bienes ofendidos y perdidos por el culpable.

Ahora, el concepto de la pena nos revela su esencia, aquello que constituye su ser, alma o entraña jurídica, pero deja sin una respuesta inmediata la pregunta por el sentido de esta clase de sanción. No porque exista una diferencia entre la entidad de la pena y su fin,

\footnotetext{
${ }^{1} \mathrm{O}$ filosofía positiva, sistema de las relaciones internas entre tales ciencias, en una palabra, epistemología, como recuerda DILTHEY, Guillermo, La esencia de la Filosofía, con un Estudio preliminar de Eugenio Pucciarelli, traducción de TABERNIG, Elsa; Buenos Aires: Editorial Losada, 1944, cfr. p. 112.
} 
contrariamente a un pensamiento que se repite como monserga desde el siglo XVII y que remata en la afirmación de que la pena poseería naturaleza retributiva y, al mismo tiempo, una finalidad de prevención. En verdad, "la naturaleza no consiste sino en la esencia de la cosa en cuanto principio de operaciones, y, por ende, comprende el fin de éstas" ". Por ende, tratar de la esencia de la pena equivaldría a construir un discurso sobre su finalidad si no fuese porque la palabra fin resulta asaz inadecuada en este orden de consideraciones. Los fines son causas psicológicas, provienen de la experiencia, indican un objetivo que se busca alcanzar, por cuyo motivo sólo cabe relacionarlos con una voluntad históricamente determinada, sea que sus designios merezcan aprobación o reprobación desde el punto de vista moral. El para qué de la pena no debiera ser confundido con propósitos éticamente ambivalentes, relativos y aleatorios. Si todo fin necesita precisamente de una justificación, entonces el asunto de la finalidad de la pena tiene que ser desplazado por una investigación de su sentido, que es la categoría en que ella recibe o queda ayuna de legitimidad.

El sentido, o lo que viene a ser igual, la razón de ser de la pena, no es asunto que se pueda acometer de la mano del concepto del Derecho, porque su ascendencia filosófica yace en otro plano, en la idea del Derecho. Nótese que no empleamos el término ideal jurídico. Los ideales, o sea, la asociación de ideas y fines, tampoco son principios absolutos de valoración, sino exigencias relativas que indican solamente el fin valorado, en nuestro caso, el modelo de la pena con arreglo a cada ordenamiento concreto, ideal que, por otra parte, puede quedar disimulado tras pomposas declaraciones constitucionales o legales cuya verdadera entidad, empero, es preciso confirmar acudiendo al plexo del sistema penal, desde la conminación hasta la ejecución de las puniciones ${ }^{3}$. El sentido de la pena, su cabal significado para la comunidad jurídicamente organizada, depende de la idea del Derecho, la única capaz de legitimar los fines concretos de la voluntad, por tanto, también la voluntad que anima a las disposiciones jurídico-penales.

Sin embargo, la palabra idea ha sido empleada en la Filosofía del Derecho con distintas acepciones, parecidamente a su destino en la Filosofía general. Unas veces designa la esencia de los fenómenos jurídicos; otras, su perfección; también ha servido para distinguir la realidad del valor; por último, puede ser presentada a la razón como un concepto supremo o limítrofe, que queda substraído a la misma razón en cuanto es uno de sus supuestos a priori. Esta última inteligencia es característica de la filosofía kantiana, que contrapone las ideas a los conceptos. Según Kant, concepto es la determinación común y unitaria de una serie de objetos análogos, a los que proporciona sus notas genéricas y en

\footnotetext{
2 Basado en la filosofía tomista, RIVACOBA Y RIVACOBA, Manuel de, redondea su observación: "Aseverar que la pena tiene naturaleza retributiva y finalidad preventiva equivale, en el fondo, a sostener que tiene fines a la vez retributivos y preventivos", como postulan algunas teorías mixtas, de la unión o complejas. Función y aplicación de la pena, Buenos Aires: Depalma, 1993, p. 32

${ }^{3}$ Así como "ocurre que los cerebros están llenos de supuestos ideales que, ante una consideración crítica, descubren su carácter de finalidades, que se convierten en auténticos ideales, una vez que reciben el placet de la idea" (MAYER, Max Ernst, Filosofía del Derecho, traducción de la $2^{\text {a }}$ edición original por LEGAZ LACAMBRA, Luis, Barcelona: Editorial Labor, 1937, p. 146), así también las proclamaciones generales de que hablamos, bastante comunes en los ordenamientos de los países latinos, pueden ocultar fines extraviados, incompatibles con las posibilidades de cada organización social o reñidos con el fin real que se desprende de la aplicación efectiva de las penas, que es el terreno en que el Derecho penal se juega el todo por el todo, incluidas las denominadas «antinomias del fin de la pena», de que luego diremos algunas palabras.
} 
cada uno de los cuales encuentra completa realización. Por su parte, las ideas son la representación armónica de todos los objetos posibles. Llevadas al mundo de los propósitos o fines, las ideas permiten articular la totalidad de los afanes humanos, aunque no podamos aguardar de ellas su plena realización en la experiencia, sino solamente una orientación, un focus imaginarius ${ }^{4}$. Expresado de otra manera, dirigen, no constituyen el entendimiento.

Queda todavía la identificación de la idea del Derecho con un valor, pero no cualquiera, sino un valor supremo, irreductible a otros valores. Este es justamente el sentido de la idea del Derecho que adoptamos para llegar desde él al sentido de la pena, un pensamiento que ofrezca la más alta síntesis teórica y, simultáneamente, la mayor extensión para la vida práctica, al cabo del cual sea hacedero atisbar "el sentido de eternidad de todo orden jurídico positivo", lo mismo que el significado último de la pena mientras haya hombres sobre la tierra. Así entendida, la idea del Derecho está llamada a cumplir una doble misión, ser un principio de enjuiciamiento del Derecho vigente, con lo que aludimos a los fines valorados por éste, y convertirse en principio de orientación para configurar el Derecho venidero. En tal pareja de tareas se percibe el parentesco de la idea estimativamente fijada, que se inspira en la filosofía de los valores contemporánea, y la idea como supuesto limítrofe de la razón, de matriz kantiano, puesto que para ambas la idea del Derecho no indica el qué, sino el cómo, esto es, sólo las formas absolutas conforme a las cuales hay que emprender la apreciación, crítica y transformación del Derecho. El parentesco aparece, además, en la relación existente entre concepto e idea del Derecho. Las dos son nociones formales y a priori, ninguna procede de la experiencia; y su entrelazamiento es por partida doble, ya que si la formación del concepto del Derecho corre el peligro de fracasar de no estar orientada según su idea, el conocimiento de la idea requiere a su vez un concepto seguro.

El debate acerca del sentido de la pena ha de girar en torno de algún valor absoluto. En cuanto tal, será un valor supraempírico, situado más allá del momento histórico de toda cultura nacional. Tiene que ser un valor intemporal de la comunidad humana, debe pertenecer a la cultura en su conjunto. Por ende, con él no tienen que ver fines, funciones ni clasificaciones, como tampoco ningún otro concepto que se mantenga en el plano de la experiencia. Repitamos que el pretenso fin de las penas señala tan sólo lo que uno o varios sujetos aspiran lograr a través de ellas, independientemente de que dicho objetivo sea o no autorizado por una idea. Así se explica que los fines penales pueden ser tantos cuantos podamos concebir, desde la realización de la voluntad o la razón divinas en nuestro mundo sublunar — como en la antigua teoría retributiva de Stahl, De Maistre y Jarcke ${ }^{6}$ —, hasta la

\footnotetext{
${ }^{4}$ Las ideas, escribe en la Crítica de la razón pura, "no tienen nunca uso constitutivo que suministre conceptos de ciertos objetos [...]. Pero, en desquite, tienen un uso regulador excelente e indispensable y necesario: el de dirigir el entendimiento hacia un cierto fin que hace converger las líneas directivas que siguen todas sus reglas hasta un punto que por no ser más que una idea (focus imaginarius), es decir, un punto de donde los conceptos del entendimiento no parten realmente, puesto que se halla colocado fuera de los límites de la experiencia posible, sirve, sin embargo, para procurarles la más absoluta unidad con la más absoluta extensión". KANT, Manuel, Obras selectas. Crítica de la razón pura y Crítica de la razón práctica, traducción de FERNÁNDEZ NÚÑEZ, Manuel, MIÑANA Y VILLAGRAÑA, E., y GARCÍA MORENTE, Manuel; Buenos Aires: El Ateneo, $2^{\mathrm{a}}$ ed., 1961, p. 560 (Apéndice a la dialéctica trascendental).

${ }^{5}$ MAYER, Filosofía del Derecho, cit. nota n ${ }^{\circ}$ 3, p. 143.

${ }^{6} \mathrm{O}$ la retribución moral de Kant, que padece del mismo defecto consistente en imaginar que una ley natural exigiría la pena como restauración del orden violado por el delito, "una supervivencia de antiguas creencias
} 
poco menos ambiciosa pretensión de educar al condenado adulto para hacerlo mejor y que no delinca, un contrasentido que tiene que provocar "una atmósfera de desconfianza por una parte y de obstinación por la otra, en que la educación apenas puede prosperar"7. Tampoco las funciones que se le asigna guardan relación con el valor que fundamenta el sentido de la pena. El concepto de función es sociológico, no filosófico-jurídico. Funciones del Derecho son las tareas que éste cumple efectivamente en la realidad, sus efectos en la vida de los individuos y el sistema social. Se trata de una noción empírica análoga a los fines, cuya investigación compete a la Sociología del Derecho. Ésta podrá mostrarnos que el Derecho orienta o confunde los comportamientos, resuelve o agudiza los conflictos, configura o desfigura la vida colectiva, promueve u obstaculiza el cambio social. Función del Derecho equivale a lo que éste hace, no aquello que debiera hacer, relativa (según los ideales jurídicos) o absolutamente (según la idea del Derecho), pese que a menudo los penalistas contemporáneos, en especial los adeptos del funcionalismo, gustan de presentar funciones como si fuesen fines o ideales, intercambiando así informaciones fácticas con aspiraciones subjetivas, ocasionalmente revestidas con una pátina de valor. Por lo demás, la pena, con lo que nos referimos a la pena ejecutada — porque al margen de la ejecución no pueden darse fines, funciones y tanto menos un sentido en ella ${ }^{8}$ - , parece que ha cumplido históricamente tareas inconvenientes para la sociedad, amén de muy gravosas en sus consecuencias sobre los individuos y familias que debieron sufrirla, sin que, por otra parte, haya servido para una prevención efectiva de ulteriores delitos. En verdad, sobre lo último el sociólogo puede decirnos aproximadamente cuántos delitos han sido cometidos pese a las penas impuestas, pero no los que éstas permitieron precaver ${ }^{9}$.

mágicas que derivan de una confusión entre Derecho y naturaleza”. FERRAJOLI, Luigi, Diritto e ragione. Teoria del garantismo penale, prefazione di Norberto Bobbio, Roma-Bari: Editori Laterza, 1989, p. 241. Incluso Nagler, pese a insistir en el carácter estrictamente jurídico de la retribución del delito, reconoció que tiene en el espíritu humano la misma raíz que retribución divina, moral y social. NAGLER, Johannes, Die Strafe. Eine juristische-empirische Untersuchung, Aalen: Scientia Verlag, 1970 (reimpresión de la edición de Leipzig, 1918), cfr. pp. 569-570. Acerca de la retribución divina de Stahl, De Maistre y Jarcke, cfr. JIMÉNEZ DE ASÚA, Luis, Tratado de Derecho penal, publicados, 7 vols., Buenos Aires: Losada, t. II, $2^{\text {a }}$ ed., 1950, pp. 39-40.

${ }^{7}$ RADBRUCH, Gustav, "La idea educativa en el Derecho penal", en su libro El hombre en el Derecho. Conferencias y artículos seleccionados sobre cuestiones fundamentales del Derecho, traducción de DEL CAMPO, Aníbal, Buenos Aires: Depalma, 1980, p. 68.

8 "Toda pena es pena finalista. El fin jurídico de toda pena [...] se alcanza plenamente con la ejecución penal. No hay fin penal al margen de la ejecución”, escribió BINDING, Karl, Compendio di Diritto penale. Parte generale, prefazione, note e traduzione sulla ottava edizione tedesca di Adelmo Borettini; Roma: Athenaeum, 1927, p. 407. Este exactísimo pensamiento, que se lee también en otros penalistas antiguos y modernos, permite reducir hasta eliminarlas las teorías (de la coacción psicológica, advertencia o intimidación) para las que la pena está llamada a prevenir delitos en general, como pena conminada o amenaza penal, paralogismo que esconde el hecho de que la penalidad no establece diálogo racional alguno con nadie y, al revés, "es tal porque está destinada a efectuarse por medio de la irrogación de la pena a individuos «singulares»y «reales»" (FERRAJOLI, Diritto e ragione, cit. nota $\mathrm{n}^{\circ}$ 6, p. 268). Lo admiten aun autores que atribuyen alguna misión preventiva a la pena sólo anunciada por la ley, como ROXIN, Claus, Derecho penal. Parte general, 2 vols., t. I (Fundamentos. La estructura de la teoría del delito), traducción de la $2^{\mathrm{a}}$ ed. alemana y notas por LUZÓN PEÑA, Diego-Manuel DÍAZ Y GARCÍA CONLLEDO, Miguel, y DE VICENTE REMESAL, Javier, Madrid: Editorial Cívitas, 1997, cfr. p. 93.

9 "Solamente son accesibles al observador y al registro estadístico aquellos casos en que la fuerza disuasiva de la amenaza penal no ha tenido ningún valor", advirtió MAYER, Max Ernst, Derecho penal. Parte general, traducción de POLITOFF LIFSCHITZ, Sergio, con revisión general y prólogo de GUZMÁN DALBORA, José Luis, Montevideo-Buenos Aires: Editorial B. de F., 2007, p. 529. Esto aparte, una enseñanza lapidaria de 
De otro lado, el análisis de los sentidos posibles de la pena hará bien en precisar con exactitud el significado de las doctrinas penales y, acto seguido, ponerse al reparo de cierta clasificación convencional de una parte del contenido de éstas. Si entendemos rectamente el concepto, doctrinas penales son el conjunto de doctrinas generales que se puede proclamar en el campo punitivo con un carácter absoluto. Antes se explicó que van mucho más allá del circunscrito asunto del sentido de la punición, así como que éste no puede ser separado tajantemente del ser de la pena, la entidad del delito, el fundamento del ius puniendi y los condicionamientos políticos que circundan todos estos elementos. Sin embargo, en los hechos las doctrinas en cuestión se han limitado mayoritariamente al problema de la finalidad del castigo, ocurrido lo cual "no es el Derecho penal, sino la pena, no la totalidad, sino una mitad el objeto de consideración"10.

Así ocurrió que el télos de la punición se viene prestando desde comienzos del siglo XIX para clasificar tales doctrinas, las que quedaron reducidas a otras tantas concepciones, no de la pena real, sino otra imaginaria, "tal como ella se introduce por el creador de la teoría en el orden jurídico ideal, cuyo creador es él mismo"11. La clasificación, pues, lleva la marca del corte inferido en su punto de arranque, una mutilación del contexto filosófico-jurídico en que se inserta el sentido de la pena. Por lo demás, la figura histórica evocada por Bauer, Röder y otros penalistas del pasado, tampoco entendió trazar una clasificación con materiales tan simples como los expresados en las frases latinas punitur quia peccatum est y punitur ne peccetur. Invocando a Platón, Séneca se limita a tomar decidida postura a favor de que la pena mire al futuro, para que el que cometió una falta no la repita, y a rechazar, con idéntica rotundidad, que sea lícito castigarle por el hecho realizado, "porque la ley no se enfurece, sino que previene"12. Siendo así, es fácil captar el problema que se cela tras la distinción de unas teorías absolutas, que postulan la pena como un fin en sí misma, otras relativas, que la contemplan como un medio para fines extrínsecos a delito y delincuente, y mixtas o eclécticas las últimas, con su monstruo de la pena como fin y medio al mismo tiempo. Sólo se puede hablar de unos fines y medios si primero se esclarece la necesaria referencia de unos y otros. La referencia descansa en una idea, un pensamiento absoluto, el valor puro que se corresponde con la esencia de la pena y en que ésta alcanza su sentido. Por eso, tampoco pueden darse "antinomias en los fines de la pena". En

la Criminología crítica yace en la relativización del poder preventivo de la pena, habida cuenta del bajo número de delitos para los que el Derecho penal cobra efectiva aplicación, cifra incluso irrisoria en algunos de ellos, como el hurto. Esto aparte, es sabido en la Sociología y Psicología criminales cómo en la prevención de las infracciones son decisivos factores que nada tienen que ver con la persecución y ejecución penal.

${ }^{10}$ Esta constatación de MAYER, Derecho penal, cit. nota $n^{\circ} 9$, p. 516, se queda un tanto corta, porque el sentido de la pena constituye apenas uno de los cuatro grandes temas de la Filosofía jurídico-penal, no la mitad. Las auténticas escuelas penales "toman posición sobre muchos otros problemas, como el método más conveniente o la esencia de la imputabilidad”. RODRÍGUEZ DEVESA, José María, Derecho penal español. Parte general, decimotercera edición revisada y puesta al día por Alfonso Serrano Gómez, Madrid: Dykinson, 1990, p. 883.

${ }^{11}$ Mayer, Derecho penal, cit. nota $\mathrm{n}^{\circ}$ 9, p. 517.

12 SÉNECA, Lucio, Sobre la ira, en sus Tratados filosóficos, tragedias, epístolas morales, prólogo de José María Pemán y traducción de AZAGRA, J., Madrid: EDAF, 1964, pp. (331-500) 418. Cattaneo anota que esta condena de la venganza y defensa de la prevención no parece que pretendía ordenar nada. Cfr. CATTANEO, Carlo, Pena, diritto e dignità umana. Saggio sulla filosofía del diritto penale, ristampa aggiornata, Torino: Giappichelli Editore, 1998, p. 55. Pero, una vez desfigurado, la clasificación elaborada sobre este pensamiento tenía que incurrir en múltiples equivocaciones. Una de las más importantes fue considerar que la reparación sería una teoría relativa, no otra tan absoluta como la retribución. 
realidad, son conflictos entre concepciones diversas acerca de la idea del Derecho. De éstas, como asimismo de la eventualidad de que semejantes conflictos sean una contradicción de la idea del Derecho consigo misma ${ }^{13}$, y, en fin, de una vía con que superarlos a propósito del sentido de la pena, nos ocuparemos a continuación.

\section{Ideas del Derecho y sentido de la pena}

Dado que el espectro de posibilidades ofrecido por la idea del Derecho no es tan cuantioso como las que proponen los criminalistas acerca del fin de la pena, podemos atenernos a las más aceptadas en la Filosofía jurídica y calibrar su resonancia en nuestro tema. La pregunta por el sentido de la penalidad tiene distintas respuestas al tenor de tres ideas diferentes del Derecho: justicia, seguridad jurídica y utilidad.

En el controvertido problema de la justicia, cuyo concepto describe a lo largo del tiempo una parábola que la ha asociado sucesivamente a un atributo de la divinidad, una virtud, una idea $y$, finalmente, un valor, sin olvidar las posiciones que intentan extraerla de consensos o discursos argumentales, ni a quienes la descartan por entender que sería un ideal irracional, existe un núcleo, generalmente compartido, que se expresa en la teoría aristotélica de la igualdad. "La justicia nos ofrece, ante todo, la figura de la justicia igualitaria, para fundamentar en ella la pena. Como a la mercancía el precio, al trabajo el salario, y a los daños la indemnización, correspondería también al delito la pena, es decir, como retribución" $"$.

La justicia igualitaria - sinalagmática o correctiva - posee la ventaja de unir firmemente la pena al delito cometido y a nada más que él. Con ello, esta especie de justicia preserva el lazo de concepto e idea de la pena y, sobre todo, exige que entre pena y delito exista alguna proporción. En un sedimento de justicia, en efecto, se hunde la raíz proporcional que los penalistas acostumbran a atribuir a la teoría retributiva ${ }^{15}$. Sin embargo, contrariamente al indicio de las apariencias, la igualdad, la proporción aritmética en las relaciones involuntarias, en suma, la justicia correctiva de Aristóteles, no desemboca en la retribución de los delitos. Esta justicia se presta tan poco para deducir de su seno un sentido retributivo en la pena, como que jamás podría trabarse una verdadera relación de equivalencia entre la pena y el delito. El propio Aristóteles, luego de excluir de sus disquisiciones el talión, "que no conviene ni con la justicia distributiva, ni con la justicia reparadora y represiva", a pocas líneas de abogar por la necesidad de comparar bajo otro respecto las cosas que están sujetas

\footnotetext{
${ }^{13}$ Cfr. RADBRUCH, Gustav, "El problema de la idea del Derecho", en su libro Tres estudios de Filosofía del Derecho y una arenga para los jóvenes juristas, traducción, introducción y notas de GUZMÁN DALBORA, José Luis, Montevideo-Buenos Aires: Editorial B. de F., 2013, pp. (59-69) 65.

${ }^{14}$ RADBRUCH, Gustav, Filosofía del Derecho, traducción de MEDINA ECHAVARRÍA, José, Madrid: Editorial Revista de Derecho Privado, $3^{\text {a }}$ ed., 1952, p. 215.

${ }^{15}$ Son muchos los que han subrayado cómo gracias a la retribución pudo entrar en la casa del Derecho penal el pensamiento que proporciona la punición al acto delictuoso, de los que basta el recuerdo de dos mentes jurídicas tan bien dotadas filosóficamente como M. E. Mayer y G. Bettiol. En el acápite siguiente volveremos sobre el punto.
} 
a alguna forma de cambio ${ }^{16}$, reconoció que la apetecida unidad de mensuración es arbitraria y convencional, o sea, extrínseca al concepto de justicia.

Y no es sólo que la justicia se muestra incapaz de proveer una ecuación que haga mensurables las realidades heterogéneas de delito y pena, como no fuere un elemento externo que, por lo mismo, sería añadido a la retribución y, en definitiva, tan arbitrario para ésta como inconciliable con la igualdad distintiva de la justicia ${ }^{17}$. Tampoco puede entregarnos la base con que construir un sistema penal, ni siquiera en su versión de justicia distributiva, el suum cuique tribuere. Porque ¿cuál tendría que ser el criterio con el que dar a cada delincuente aquello que merece: su culpabilidad, la gravedad del daño causado, la peligrosidad del sujeto para los demás, la frecuencia de conductas análogas en la comunidad?

En resumen, el supuesto vínculo necesario de justicia y retribución naufraga en los dos aspectos más caros al pensamiento retributivo. Por una parte, la justicia "no nos da pauta alguna con la cual medir la igualdad o desigualdad de esa gravedad del delito, la culpa, la peligrosidad u otra cualquiera, y, por otra, sólo nos habla de la relación de las penas entre sí, pero nada sobre su rango y clases" ${ }^{\prime 1}$. Es más, como la justicia distributiva puede acaso determinar la clase y el grado de pena dentro de un sistema penal dado, pero no el sistema en sí, resulta que el Derecho penal fundado en ella, al que erróneamente se califica de retributivo, tiene dos desenlaces tan factibles como extremosos, la justicia del totalitarismo, con su vocación excluyente y homicida, o la justicia de la individualización, a la que obsede la manía de corregir la «actitud interior antijurídica» (la Gesinnung de los alemanes) y cuyo lógico punto de arribo es el Derecho penal de autor. Es la justicia aliada a fines de utilidad, de los que pronto haremos mérito ${ }^{19}$.

16 "No hay, pues, verdadera reciprocidad, sino cuando se han igualado las cosas de antemano", leemos en la Moral, a Nicómaco, Lima: Editorial Universo, 1967, p. 121. Pero se trata de un giro de la justicia sobre sí misma, de fundar la justicia igualitaria en la justicia distributiva, esa que exige tratar igualmente a los iguales y desigualmente a los desiguales. A fin de cuentas, "la justicia es siempre nada más que abstracción de una desigualdad dada desde cierto punto de vista". RADBRUCH, "El problema de la idea del Derecho", cit. nota $\mathrm{n}^{\circ} 13, \mathrm{p} .62$.

${ }^{17}$ Röder llevó la crítica hasta el extremo de afirmar que faltaría todo punto de comparación entre pena y delito. Del Vecchio afirma que, de existir, sería una comparación cerebrina. Cfr. RÖDER, Carlos David Augusto, Las doctrinas fundamentales reinantes sobre el delito y la pena en sus interiores contradicciones, traducción de GINER, Francisco, Pamplona: Analecta, 1999 (edición facsimilar de la de Victoriano Suárez, Madrid, 1876), p. 60, y DEL VECCHIO, Giorgio, "Sobre el fundamento de la justicia penal", Apéndice de su libro La justicia, traducción de LAPLAZA, Francisco P., Buenos Aires: Editorial Depalma, 1952, pp. 218219.

En todo caso, es claro que los penalistas tenemos que contentarnos con que los factores de apreciación se construyan según un determinado ideal cultural, que en la época contemporánea son el tiempo y el dinero. El problema es que precisamente éstos son relativos, nos dejan en la estacada y no permiten avanzar en la búsqueda del sentido de la pena con arreglo a la idea de la justicia.

${ }^{18}$ RADBRUCH, Filosofía del Derecho, cit. nota n 14, p. 216.

${ }^{19}$ En nuestro estudio sobre la individualización de la pena señalamos que pertenece a la esencia del concepto una inspiración valorativa transpersonal, vertida políticamente en comprensiones substancialistas de la sociedad y del Estado. No altera esta conclusión que en ocasiones los afanes individualizadores se presenten revestidos con atavíos de sedicente humanismo, como en la ideología de la resocialización. Cfr. GUZMÁN DALBORA, José Luis, "La «individualización» de la pena: contenido, trayectoria histórica y crítica del concepto", Revista de Ciencias Sociales, Facultad de Derecho y Ciencias Sociales de la Universidad de Valparaíso, $\mathrm{N}^{\circ} 56$ (2010), pp. 113-134. 
Por su parte, la seguridad jurídica es una idea mucho más definida que la escurridiza justicia, hasta el punto que algunos iusfilósofos la consideran el único valor propio del Derecho, el solo que poseería una significación estrictamente jurídica ${ }^{20}$. En todo caso, no hay que confundirla con la seguridad individual, la seguridad por medio del ordenamiento jurídico, aquella "que el Derecho nos confiere al garantizar nuestra vida o nuestros bienes contra el asesinato, el robo, etc." 21 . En seguida, la seguridad jurídica no es sinónimo de la certeza del Derecho, que algunos sociólogos denominan seguridad de orientación, ese valor que reclama que los justiciables dispongan o, a lo menos, puedan disponer efectivamente de un conocimiento adecuado acerca de las normas que rigen su conducta jurídica, de suerte que queden en condiciones de comportarse según ellas. La certeza es condición indispensable para la realización de la seguridad como tal, que sería quimérica si las personas ignoran lo que está jurídicamente prohibido y permitido. En este aspecto, la certeza posibilita la acción y la hace libre, no la deja librada al movimiento de una voluntad errátil y arbitraria ${ }^{22}$. Pero no es aún seguridad jurídica.

Esta segunda idea del Derecho designa el conjunto de condiciones que permiten a cada quien confiar fundadamente en que los derechos y las obligaciones que el Derecho atribuye e impone serán reconocidos y aplicados, en otras palabras, que recibirán la protección de los órganos del poder público, si es preciso mediante el uso de la fuerza socialmente organizada. La securitas, seguridad en sentido estricto, posee dos niveles. Su dimensión objetiva atañe a una situación valorada que deriva del cumplimiento de las normas y, para el evento de ser conculcadas, de la aplicación pública de las disposiciones que sancionan el incumplimiento. El pliegue subjetivo consiste en la representación de la seguridad objetiva en la psiquis de los coasociados, en el sentido que el Derecho, que se ha introducido en las relaciones interpersonales como un instrumento que pretende substraer la existencia de cada cual a las violencias y usurpaciones, ya provengan del Estado o de los particulares, transmite este efecto benéfico en las personas, aplacando en su ánimo el temor que, sin él, las dominaría.

Se piensa que a esta idea del Derecho, típica del individualismo liberal — de donde se explica que fuese la preferida por el iusnaturalismo racionalista y los padres del Derecho penal contemporáneo-, correspondería, como objetivo de la pena, la prevención general de los delitos. Existe un poso de verdad en el vínculo de aquella ascendencia filosófica y esta finalidad empírica. Con la versión negativa de la prevención general, por medio de la intimidación o lisa y llanamente el terror, hace perfecto pendant la flexión objetiva de la

\footnotetext{
20 "Es el único, en efecto, que se haya asociado del modo más estrecho a la existencia del Derecho; la seguridad jurídica queda realizada, cumplida, por el solo hecho de existir un Derecho vigente". Éste puede contribuir a la realización de otros valores, como la propia justicia, pero nada más que la seguridad jurídica es la "dimensión ontológica del Derecho, su fin a priori, al cual todo otro fin queda supeditado". MILLAS JIMÉNEZ, Jorge, Filosofía del Derecho. Estudio preliminar, notas y edición de Juan O. Cofré, Santiago de Chile: Ediciones Universidad Diego Portales, 2012, pp. 354 y 360.

${ }^{21}$ RADBRUCH, Gustav, Introducción a la Filosofía del Derecho, traducción de ROCES, Wenceslao, México: Fondo de Cultura Económica, 1985, p. 40.

22 "La certeza del Derecho se traduce en certeza de la acción. La acción deviene libre, porque está constreñida a reconocer la ley que lleva en sí y que encuentra fuera de sí, y que precluye la posibilidad de moverse sin meta como voluntad errática y arbitraria, en una cadena sucesiva de opciones que puede en cualquier instante disgregarse en las más cambiantes direcciones". LÓPEZ DE OÑATE, Flavio, La certeza del diritto, nuova edizione riveduta, a cura di Guido Astuti, Milano: Giuffrè, 1968, p. 52.
} 
seguridad jurídica. De su lado, las miras de aprendizaje, confianza y pacificación social que propugnan los partidarios de la prevención general positiva, se avienen a pedir de boca con el efecto subjetivo de la seguridad del Derecho ${ }^{23}$.

No obstante, como la justicia distributiva, la idea de la seguridad fracasa en su misión punitiva más importante, ofrecer un criterio cierto para la configuración del sistema penal, sin nombrar que tiende por sus pasos contados a expandir ilimitadamente la intensión y extensión de las puniciones. El subproducto preventivo general de la seguridad no descansa en que la pena se iguale o proporcione al delito, sino en los temores o la satisfacción de los demás - que a menudo se reducen a los grupos dominantes o el gobierno-, cuyas expectativas escapan naturalmente a toda posibilidad de estimación. En consecuencia, la seguridad, vuelo majestuoso de la burguesía en ascenso, luego petrificado con la consolidación del poder burgués, tampoco está en posición de limitar las exigencias de las cambiantes finalidades sociales, como conjeturó Radbruch, porque la misma seguridad, en el fondo, es una cristalización de la utilidad, y pronto veremos que finalidad y utilidad no pueden justificarse a sí mismas.

Cierto es que, enfocada en lo penal, la seguridad jurídica puede exhibir un rostro liberal, aquel que comprime el poder de los jueces en la red del principio legalista, el nullum crimen nulla poena sine lege. Sin embargo, no puede extraer de sí la aptitud de contener al agente de las disposiciones punitivas, el legislador. Esto aparte, la experiencia histórica es pródiga en ejemplos de utilización de reos potenciales o reales para sosegar ánimos intranquilos o promover el conformismo con la situación existente, exasperando los castigos en una espiral que culmina en el terrorismo punitivo, la seguridad de la tumba ${ }^{24}$.

Acabamos de insinuar el problema de justificación que complica al pensamiento de la utilidad o conveniencia social, la adecuación a fin (Zweckmässigkeit) de que discurrió brillantemente Radbruch. Se comprenderá que en cualquiera de estas designaciones el concepto refleja, no una verdadera idea del Derecho, sino un simple fin, la pretensión subjetiva de que el Derecho y sus instituciones, entre ellas la pena, cumplan un servicio útil para la colectividad, así como lo entiende quien se lo propone en algún momento histórico. Su lema: ¡salvar a la sociedad! dista mucho de constituir una exigencia válida en sí misma, porque todavía queda por determinar qué lo justifica y, sobre todo, cómo se ha de llevar a cabo. Con razón observa Radbruch que finalidad o adecuación a fin, en una palabra, utilidad, están necesitadas de una definición más exacta, y que "pueden encontrar su último

\footnotetext{
${ }^{23}$ Como en la vieja frase de Carrara, al que no escapó el efecto que comentamos, siquiera tampoco lo exaltó como los ardorosos secuaces del funcionalismo moderno: "La fuerza moral objetiva de la pena está representada por el resultado moral que el suplicio excita en el ánimo de los ciudadanos, tranquilizando a los buenos o sofrenando a los malos". CARRARA, Francesco, Programma del corso di diritto criminale. Del delitto, della pena, Bologna: Il Mulino, 1993, p. 414.

${ }^{24}$ La prevención general tiene que conducir a una agravación incesante de la pena, con lo que llega finalmente a la pena de muerte para todos los delitos, a matar mosquitos a cañonazos; en suma, a un Código draconiano. Sobre el particular, Rivacoba y Rivacoba, Bettiol y, mucho antes, Dorado Montero y Carrara, formularon unas admoniciones que siguen en pie. Cfr. RIVACOBA Y RIVACOBA, Función y aplicación de la pena, cit. nota $n^{\circ}$ 2, pp. 41-42, BETTIOL, Giuseppe, y PETTOELLO MANTOVANI, Luciano, Diritto penale. Parte generale, dodicesima edizione riveduta e integrata, Padova: Cedam, 1986, p. 826, DORADO MONTERO, Pedro, El Derecho protector de los criminales, 2 vols., Pamplona: Analecta, 1999, t. II, p. 40, y CARRARA, Programma del corso di diritto criminale, cit. nota $\mathrm{n}^{\circ} 23, \mathrm{p} .409$.
} 
fundamento únicamente allí donde, en definitiva, toda posición de fines ha de buscar su legitimación, a saber, en los valores absolutos",25.

Sin embargo, convertir un fin preciso, la utilidad de la pena, en una idea de fin, en aquello que la pena debe ser, depende del sistema axiológico que entre en cada caso en consideración. Estos sistemas pueden ser absolutos y relativos. Conocida es su traducción filosófico-jurídica, supraindividualista o transpersonalista $y$, respectivamente, individualista, así como notas son las ideologías políticas que les corresponden, autoritaria en el primer caso, liberal en el segundo ${ }^{26}$. Ahora, la utilidad ha sido perseguida a título de fin de la pena y presentada como su sentido con arreglo a determinadas concepciones filosófico-políticas, así por el liberalismo de izquierdas como por el autoritarismo punitivo. Uno y otro tienen en común la prevención especial, positiva o negativa en el caso del liberalismo, decididamente negativa tratándose del autoritarismo. Esta pareja de doctrinas, maguer su evidente disparidad, quiso fragmentar al hombre en tipos humanos concretos, aunque sin llegar jamás a una auténtica individualización, porque ésta responde a otra idea del Derecho y, por lo demás, hubiera arruinado los planes que aguardaban bajo el enarbolado pabellón de la utilidad social. De hecho, el paso que condujo naturalmente desde la política criminal de la Escuela positiva, pasando por la Joven escuela alemana, hasta la brutal realidad punitiva del nacionalsocialismo y el no menos crudo Derecho penal «social» del comunismo soviético, se dio a la siga de la prevención especial a través de la mejora o la inocuización del delincuente. Que la corrección sea irrealizable y, en cambio, la eliminación pueda ser emprendida eficazmente con múltiples medios, pero también la grosera utilización del condenado en pos de designios que él mismo no se ha trazado ${ }^{27}$, son antecedentes que tienen que ceder en importancia ante la principal objeción que suscita el principio utilitario cuando anuncia su silueta en el terreno de las penas. Es que, coherentemente aplicada, la prevención especial torna inútil cualquier Código punitivo. Como ninguna de las infinitas posibilidades de agresión que cabe temer del delincuente peligroso es idéntica a las demás, el sistema penal, el propio juez punitivo devienen innecesarios, incluso perjudiciales. La prevención especial de los delitos se entiende mejor con la actividad de la policía, la liquidación administrativa del problema jurídico de la criminalidad $^{28}$.

\footnotetext{
${ }^{25}$ RADBRUCH, "El problema de la idea del Derecho", cit. nota ${ }^{\circ} 13$, p. 63.

${ }^{26}$ Véanse MAYER, Filosofía del Derecho, cit. nota ${ }^{\circ} 3$, pp. 156-168, y RADBRUCH, Introducción a la Filosofía del Derecho, cit. nota ${ }^{\circ} 21$, pp. 36 y 37.

${ }^{27}$ Las doctrinas de la prevención especial, cuyos mejores exponentes columbraron, "no un Derecho penal mejor, sino algo mejor que el Derecho penal, a saber, un tratamiento racional del delincuente en el sentido de su educación y la defensa social" (RADBRUCH, "La idea educativa en el Derecho penal", cit. nota $n^{\circ} 7, \mathrm{p}$. 69), son, empero, "las más iliberales y antigarantistas que hayan sido concebidas históricamente, y justifican modelos de Derecho penal máximo y tendencialmente ilimitado". FERRAJOLI, Diritto e ragione, cit. nota $\mathrm{n}^{\circ}$ 6, p. 258.

28 "La característica del poder punitivo dentro de esta corriente es su reducción a coacción directa administrativa: no hay diferencia entre ésta y pena, pues ambas buscan neutralizar un peligro actual". Opinamos que el comentario de Zaffaroni, pensado para la prevención especial negativa, es también aplicable a la variante positiva. ZAFFARONI, Eugenio Raúl, Derecho penal. Parte general. Buenos Aires: Ediar, $2^{\mathrm{a}}$ ed., 2002, p. 64.
} 


\section{Humanidad y retribución}

El resultado alcanzado hasta el momento no es propicio para dejar en el ánimo una impresión satisfactoria. Justicia, seguridad jurídica y utilidad pueden tal vez congeniarse con finalidades retributivas, preventivo generales y preventivo especiales, pero, en desquite, esta tríada de sentidos de la pena ha revelado su ineptitud para edificar un sistema penal que guarde correlación con los delitos. Por si fuera poco, varios de estos sentidos no pasan de meros fines penales y, en todo caso, presentan el ostensible inconveniente de rebajar la condición del reo, de sujeto pasivo a mero objeto del ius puniendi. Lejos de risueño, el panorama que se despliega a nuestra vista es desalentador.

Resta por traer en causa otra idea del Derecho. Que la discusión filosófico-jurídica de nuestro tiempo la mantenga en sordina, no irroga una mengua en su radical importancia, celebrada por los prohombres de la Ilustración y sus epígonos penalistas de la República de Weimar, y hoy presente en múltiples Constituciones y el Derecho internacional sobre los derechos fundamentales. Es la idea de la humanidad, de la que apremia trazar el concepto:

"La humanidad consiste en romper mentalmente todas las vinculaciones de los hombres a sociedades históricamente dadas, para no admitir más que la pertenencia a la sociedad humana o, como también suele decirse, no atribuir ningún valor a las condicionalidades en que consiste la existencia de todo ser social, y reconocer el máximo valor a la dignidad de la persona en cuanto tal. La humanidad proclama y exige el hombre en sí."29

Si la dignidad, en cuanto valor absoluto, designa la constitución del hombre como un ser librevolente y un fin en sí mismo, parece que el único sentido de la pena que pudiera serle congruente es la retribución del delito. En la desvaloración pública, reflejada y concretada en la pena, de los actos de más grave trascendencia social, se respeta al autor de tales actos como un fin en sí, no se lo trata como un medio para fines que lo superan o trascienden. En este aspecto, la antigua objeción de Kant, que la pena no debe servir simplemente para fomentar algún bien, sea del delincuente mismo o para la sociedad civil, "porque el hombre nunca puede ser manejado como un medio para los propósitos de otro ni confundido entre los objetos del derecho real" ${ }^{30}$, conserva plena validez. Ninguna teoría preventiva ha conseguido ni logrará superar con éxito este reparo, al que Cattaneo considera una contribución esencial e irrenunciable del filósofo alemán al problema penal ${ }^{31}$.

No sólo eso. En su faz positiva, la retribución aporta ganancias enormes para la construcción de la teoría del delito. Beling y, en su estela, Bettiol y Rivacoba, dedujeron de la idea retributiva el triple corolario de que el delito requiere un acto antijurídico y culpable, ya que sólo se puede retribuir lo que un sujeto hace o cómo lo hizo, no lo que él es, la desvaloración respectiva supone la contradicción del acto con el Derecho y, por último, el juicio de desvalor carecería de sentido si el acto, pese a su antijuridicidad, no fuese además culpable. Podemos incluso estar dispuestos a admitir que sólo la retribución posibilita cierta

\footnotetext{
${ }^{29}$ MAYER, Filosofía del Derecho, cit. nota ${ }^{\circ} 3$, pp. 192-193.

${ }^{30}$ KANT, Immanuel, La metafísica de las costumbres, estudio preliminar de Adela Cortina Orts, traducción y notas de CORTINA ORTS, Adela, y CONILL SANCHO, Jesús; Madrid: Tecnos, 1989, p. 166.

${ }^{31}$ CATTANEO, Pena, diritto e dignità umana, cit. nota ${ }^{\circ} 12$, cfr. p. 115.
} 
proporción entre delito y pena, aunque no la relación firme que vislumbró Beling, como también que la pena retributiva franquea una reafirmación simbólica de los objetos valorados por las normas jurídicas y hollados por el delincuente ${ }^{32}$.

Sin embargo, continúa clavada en el costado de la idea de la humanidad la duda de si es lícito aspirar a la desvaloración de los delitos y al restablecimiento ideal de las normas infringidas, haciendo al delincuente el hegeliano honor de sufrir una pena cuya única coordenada es el acto que él ejecutó o, con menor deferencia, enrostrándole que su "dolor sirve para la salvaguardia cognitiva de la vigencia de la norma" "33. Este último aristocrático ademán traiciona el pliegue inhumano y contracultural del pensamiento retributivo. En efecto, no puede ser afín con las valoraciones comunitarias el prurito de asegurarlas a golpes, según una visión retrospectiva que momifica en vez de vivificar el pasado, así como tampoco se puede filosofar a martillazos, y, en otro sentido, la conciliación de humanidad y retribución según la humanísima consigna de "retribuir cuanto sea preciso y hacer sufrir sólo lo mínimo indispensable" 34 , pasa por alto que, aun así, la pena retributiva sigue diciendo al hombre que la sufre que su padecimiento, en el que se consideró aquello que él hizo, pero no sus consecuencias, es un completo sinsentido ${ }^{35}$.

Hemos topado con un callejón sin salida. La idea de la humanidad, incompatible con la prevención penal, mejor avenida con la retribución, parece reclamar algo mejor que la pena retributiva, pero sin hacer renuncia - en una peligrosísima "despedida de Kant y Hegel"36 — al único aspecto en que ésta supera con largueza a todas las demás finalidades de la pena.

\section{La reparación y el sentido de la pena}

Aquí el penalista no tiene más remedio que acudir al filósofo. Bueno sería que alguna vez se dirija a los representantes del romanticismo en filosofía, tan denostados por el pensamiento jurídico. Un enigmático aforismo de Friedrich Schlegel, cuya estampa descuella en el panorama intelectual de las postrimerías del Siglo de las Luces, reza así: "Es

32 Cfr. BELING, Ernst von, Die Vergeltungsidee und ihre Bedeutung für das Strafrecht, Aalen: Scientia Verlag, 1978 (reimpresión de la edición de Leipzig, 1908), pp. 52-62, BETTIOL/PETTOELLO MANTOVANI, Diritto penale, cit. nota ${ }^{\circ} 24$, pp. 808-813, y RIVACOBA Y RIVACOBA, Función y aplicación de la pena, cit. nota $\mathrm{n}^{\circ} 2$, pp. 73-76.

33 "Éste es el fin de la pena, como la contradicción de la negación de la vigencia de la norma por parte del delincuente es su significado". JAKOBS, Günther, La pena estatal: significado y finalidad, traducción de CANCIO MELIÁ, Manuel, y FEIJOO SÁNCHEZ, Bernardo; Navarra: Aranzadi, 2006, p. 141.

${ }^{34}$ RIVACOBA Y RIVACOBA, Función y aplicación de la pena, cit. nota $\mathrm{n}^{\circ} 2$, p. 83 (el original, en cursivas). Yo mismo, que adherí durante muchos años a la finalidad retributiva de la pena, terminé convenciéndome de que la orientación humanizadora del pasaje citado es sencillamente de imposible realización al hilo de tal finalidad.

${ }^{35}$ El pensamiento retributivo ciertamente que toma en cuenta, y en primerísimo lugar, el efecto antijurídico de la acción punible, en la medida que quepa atribuirlo subjetivamente al hechor. Sin embargo, no le inquieta que la pena pudiese reobrar sobre tal efecto, como no sea en una dirección en verdad ajena a éste, la reafirmación especulativa del bien jurídico ofendido o, en su versión peor, de la norma infringida. Esto es lo que queremos decir con la desconsideración retributiva de las consecuencias del delito.

${ }^{36}$ KLUG, Ulrich, "Despedida de Kant y Hegel. (Una crítica filosófica básica”), en su libro Problemas de la Filosofía y de la pragmática del Derecho, traducción de SEÑA, Jorge M., México: Fontanamara, 2002, pp. 31-36. 
propio de la humanidad el que tenga que elevarse por encima de la humanidad" ${ }^{\text {37 }}$. En verdad, la pena retributiva es humana, pero demasiado humana, propia de una humanidad reconcentrada, egoísta e infértil. Va de suyo que la superación de la humanidad no puede consistir en un «seréis como los Dioses», precisamente porque no lo somos. Sin embargo, cuando el hombre adquiere conciencia de la conexión que existe entre todas las cosas, incluso las que parecen más lejanas unas de otras, intuirá también que el único sentido constitutivamente humano de la pena, en tanto ésta haya de ser necesaria en las sociedades humanas, coincide con la reparación del daño producido por el delito.

"La pena podría perder algo de ilegitimidad como sanción reparadora si se la redujese a una coacción que obligase a la reparación" 38 . Merece la pena retener esta idea para el efecto de no incurrir en graves confusiones, que aniquilan de entrada las virtualidades de la reparación en el Derecho penal. Sus tímidas muestras actuales, como alternativa a penas y medidas, causa de atenuación de la responsabilidad criminal, reconocimiento del papel procesal de las víctimas, etc., equivocan medio a medio el concepto. La reparación no persigue compensar un daño a la vigencia de las normas, tarea para la que son igualmente ineptos el Derecho civil y el Derecho penal ${ }^{39}$. Tampoco es su objetivo indemnizar perjuicios, cuestión que, en cambio, pertenece al Derecho privado ${ }^{40}$. No tiene que ver con

${ }^{37}$ SCHLEGEL, Friedrich, O dialeto dos fragmentos, tradução, apresentação e notas de SUZUKI, Márcio São Paulo: Iluminuras, 1997, p. 147.

${ }^{38}$ ZAFFARONI, Derecho penal, cit. nota $n^{\circ} 28$, p. 47. La reparación como pena ha sido defendida en Alemania por Sessar y Schild, cuyas doctrinas al respecto resume ALASTUEY DOBÓN, M. Carmen, La reparación de la víctima en el marco de las sanciones penales, prólogo de José Cerezo Mir, Valencia: Tirant lo Blanch, 2000, cfr. pp. 105-109, criticándolas con el equivocado argumento de que así se difuminaría el deslinde entre Derecho penal y Derecho civil, pena e indemnización de daños y perjuicios. Véase, infra, nota 40.

${ }^{39}$ Sólo la teatralización idealista decimonónica se juzga autorizada para sostener que la pena es capaz de anular el delito y restablecer el Derecho o, como sostienen sus secuaces actuales, mantener la vigencia de las normas. De la primera, HEGEL, Guillermo Federico, Filosofía del Derecho, introducción de Carlos Marx, traducción de MENDOZA DE MONTERO, Angélica, Buenos Aires: Editorial Claridad, 1955, cfr. p. 106; de los segundos, JAKOBS, Günther, Bases para una teoría funcional del Derecho penal, Lima: Palestra Editores, 2000, cfr. pp. 24-35. Contrariamente a esta vana palabrería, la pena, a lo menos la pena como la entendemos desde finales de la Edad Media, es una patente demostración de que una norma fue violada, con lo cual hace un flaco servicio a su majestad.

${ }^{40}$ Una persistente, pero infundada objeción a la reparación como sentido de la pena, aduce que borraría la frontera de Derecho penal y Derecho civil, confundiendo la pena con una indemnización de daños y perjuicios a la que de todos modos tiene derecho el perjudicado. Así, por ejemplo, HIRSCH, Hans Joachim, "La posición del ofendido en el Derecho penal y en el Derecho procesal penal, con especial referencia a la reparación", traducción de SÁNCHEZ OCAÑA, Roberto, Cuadernos de Política Criminal, de Madrid, $\mathrm{N}^{\circ} 42$ (1980), cfr. pp. (561-575) 565, 566 y 569, y ALASTUEY DOBÓN, La reparación de la víctima en el marco de las sanciones penales, cit. nota $\mathrm{n}^{\circ} 38$, cfr. pp. 23, 24, 111, 137, 221 y otras. Ahora bien, pena e indemnización comparten nada más que el hecho de pertenecer a un subgénero de sanciones en que el contenido u obligación impuesta al sancionado no coincide con la conducta prescrita por la norma infringida u obligación condicionante. Sin embargo, mientras la indemnización del daño persigue lograr un acatamiento por equivalencia con el deber original quebrantado, lo que supone naturalmente efectuar un cálculo económico de los daños y perjuicios, este no es el caso de la pena reparadora. Es más, la pena tradicional tiene algo de la indemnización del daño, en la medida que su graduación se basa en juicios métricos de valor, que traducen cuantitativamente en tiempo o dinero la gravedad de lo injusto culpable. En cambio, la pena entendida como coerción reparadora supone una transformación cualitativa de las valoraciones, para lo cual no sirven ciertamente los juicios métricos de valor. Reducirlas no a un tanto, sino convertirlas en otro, 
designio preventivo alguno, porque responde a una idea tan absoluta como la retribución, de lo que se sigue, entre otras cosas, que no hay por qué esperar en el penado una actitud de remordimiento, que se reconcilie con la víctima, tanto menos exigir que haya mantenido hasta la fechoría una conducta penalmente intachable ${ }^{41}$. Tampoco elucubraciones de prevención general debieran impedir que la reparación tome siempre la primera palabra. Es practicable en cualesquiera infracciones, incluso los delitos que no han tenido una víctima directa, en lo que conviene recordar que los sistemas medioevales de composiciones, de indiscutible carácter penal, se extendían a prácticamente todos los maleficios, comenzando por el homicidio ${ }^{42}$. Por último, la pena reparadora es pena, por tanto, una pérdida o limitación de bienes jurídicos que se impone en contra de la voluntad del condenado. No tiene por qué implicar la eutanasia del Derecho penal ni la disolución de la pena como sanción pública de supina gravedad ${ }^{43}$.

Mirada positivamente, este sentido de la pena perfecciona y concreta los postulados de la humanidad, la dinamiza, desarrolla y supera con la apreciación de las circunstancias reales del semejante y las condiciones efectivas del sistema penal. En esto, semeja el tránsito que

demanda un juicio de semejanza cualitativa; no un concepto axiológico numérico, sino un concepto análogo de relación; una transformación variable en vez de otra monótona.

Demostración reciente de que no son lo mismo indemnización y reparación, la ministran las condenas pronunciadas contra diversos Estados del continente por la Corte Interamericana de Derechos Humanos. El concepto de reparación que manejan esos fallos, relativamente al artículo 63 de la Convención americana de 1969 (que, por lo demás, distingue con toda claridad reparación de indemnización), revela a pedir de boca la diferencia cualitativa entre los dos conceptos, que responden a dos especies distintas dentro del género de las sanciones jurídicas. No es verdad, pues, que la pena reparadora fagocite el Derecho penal en el Derecho civil. Acerca de la individualidad de la indemnización de perjuicios en el sistema de sanciones en general, véase GARCÍA MÁYNEZ, Eduardo, Introducción al estudio del Derecho, México: Porrúa, 48 a ed., 1996, pp. 298302. En contra de su identificación con la pena se pronunciaron CARRARA, Programma del corso di diritto criminale, cit. nota $\mathrm{n}^{\circ} 23$, cfr. pp. 329-331, y, todavía más enfáticamente, BINDING, Karl, Die Normen und ihre Übertretung. Eine Untersuchung über die rechtsmässige Handlung und die Arten des Delikts, 4 vols., Leipzig: Verlag von Wilhelm Engelmann, t, I, 1872, pp. 166-172. De la naturaleza jurídica de la reparación y su diferencia respecto de la indemnización trata extensamente GALAIN PALERMO, Pablo, La reparación del daño a la víctima del delito, Valencia: Tirant lo Blanch, 2010, pp. 90, 126. Sobre el artículo 63 de la Convención de 1969, véase CORREA, Cristián, en: STEINER, Christian, y URIBE, Patricia (Eds.), Convención americana sobre derechos humanos. Comentario, Bogotá: Konrad Adenauer Stiftung, 2014, pp. 817-888 (en p. 838 explica que la "justa indemnización”, de que habla el artículo 63, es compensatoria, no sancionadora). Acerca de la jurisprudencia de la Corte interamericana en materias penales y reparación, AMBOS, Kai, MALARINO, Ezequiel, y STEINER, Christian, (Eds.), Sistema interamericano de protección de los derechos humanos y Derecho penal, 3 vols., Bogotá: Konrad Adenauer Stiftung, t. III, 2013, pássim.

${ }^{41}$ Está completamente fuera de lugar en una sala de justicia someter al delincuente a un "ritual de disculpas", como si la pena fuese una forma de "expiación". Así, sin embargo, lo plantea la teoría comunicativa de DUFF, Anthony, Sobre el castigo. Por una justicia penal que hable el lenguaje de la comunidad, traducción de PONS, Horacio, revisada por ROTH, Laura, Buenos Aires: Siglo Veintiuno Editores, 2015, cfr. p. 58.

${ }^{42}$ Pero excluidos los hechos de traición al rey y, después, ciertos delitos religiosos, lo primero en obsequio al absolutismo político, lo segundo en aras del poder terrenal de la Iglesia. Cfr. SBRICCOLI, Mario, Crimen laesa maiestatis. Il problema del reato político alle soglie della scienza política moderna, Milano: Giuffrè, 1974, pp. 187, 201 y 204.

${ }^{43}$ En este sentido, la pena reparadora es pena «merecida». Descansa en las ideas de humanidad y justicia al mismo tiempo, pero no tiene que ver con la llamada «justicia restauradora». En esto nos hallamos de acuerdo con ROBINSON, Paul, Principios distributivos del Derecho penal. A quién debe sancionarse y en qué medida; traducción e introducción de CANCIO MELIÁ, Manuel, y ORTIZ DE URBINA, Íñigo; Madrid: Marcial Pons, 2012, cfr. pág. 241. 
va desde la dicotomía Derecho penal liberal y autoritario, a la antítesis Derecho penal humano e inhumano que preconiza últimamente Zaffaroni ${ }^{44}$. Elevándose por encima de la humanidad, nuestro ideal jurídico solicita que se imprima a las penas el sentido auténticamente racional y armónico con la índole pensante de los seres humanos, que no es otro sino remediar el daño causado por el delito o las consecuencias nocivas directamente ligadas a él, sea mediante una recomposición directa, sea subsanándolo mediante una prestación substitutiva o conductas simbólicas. La recomposición directa del estado anterior es factible en todos los delitos cuyo resultado no consiste en la destrucción del bien protegido, sino en un daño parcial o el menoscabo de su disponibilidad o ejercicio por el titular, por ejemplo, realizando el falsario de moneda actos que coadyuven a la fe pública, incluyendo trabajos para el ente emisor, o cometiéndose al reo de cohecho la tarea de colaborar en políticas y prácticas de prevención de este delito en los cuerpos administrativos. Las prestaciones substitutivas y las acciones simbólicas son procedentes en las infracciones de lesión absoluta, como el homicidio o la violación. Si el sujeto mató a un niño o a un anciano, ¿por qué no imponerle como pena la prestación substitutiva consistente en criar a un infante huérfano o asistir a un viejo menesteroso? Y de no ser posible la substitución, como en algunos delitos sexuales, están a la mano diversas conductas simbólicas, esto es, representativas de la idea y del concepto encerrados en el bien de que se trate, tanto en la forma de acciones como omisiones, $v$. gr., promover figurativamente el estatuto jurídico de mujeres, niños, homosexuales, etc., o abstenerse por un tiempo de la relación con ciertos grupos de personas ${ }^{45}$. En resumen, analogía cualitativa de pena y delito, pues "la justificación intrínseca de la pena radica, precisamente, en su función reparadora y reintegradora del derecho lesionado", como "una actividad en sentido contrario a la del mismo autor del delito, la cual anule o reduzca los efectos de este último, en la medida de lo posible"46.

\section{Conclusiones}

Semejante orientación ofrece a los sistemas penales una miríada de posibilidades, ninguna de las cuales podría macularse con una ofensa a la humanidad, porque en esta idea tienen

\footnotetext{
${ }^{44}$ La nueva antítesis "importaría pasar de lo relativamente estático a lo eminentemente dinámico, de la realidad a su superación, de lo deducido de modelos ideales a lo inducido de la racionalización de experiencias criminales, de lo opinable a lo impuesto por la Constitución, de la pretensión perfeccionista a la realización de lo más humano (o de lo menos inhumano) posible, y de una dinámica ideológica y casi siempre idealista a una confrontación de fuerzas necesariamente realista". ZAFFARONI, Raúl, "¿Derecho penal humano o inhumano?", Revista de Derecho penal y Criminología, de Buenos Aires, año IV, N 8 (2014), pp. (3-15) 15.

${ }^{45}$ En esto es oportuno advertir dos cosas. Primero, la conducta simbólica en modo alguno debe confundirse con la pena infamante de antaño. La penalidad infamante consistió en el escarnio público del condenado (mediante atavíos humillantes, señas u objetos que recuerden la fechoría, inmersión en charcos o ríos, decalvación, berlina, etc.), antes que en actos que él debía realizar. Segundo, la aptitud restauradora de los símbolos es bien conocida en el arte merced al desarrollo del simbolismo en la pintura, la escultura, la poesía y el teatro, con su afán, no de describir la realidad, sino expresar un ideal a través de las afinidades secretas que existen entre el mundo sensible y el espiritual. Tenemos presente el Efecto nocturno, de Paul Verlaine, poema que asocia en su horror sin sentido el desolador panorama de un cielo incoloro y desgarrado, unos matorrales espinosos y acebos de espanto, con las delgadas siluetas pendientes de algunos ahorcados.

${ }^{46}$ DEL VECCHIO, "Sobre el fundamento de la justicia penal”, cit. nota ${ }^{\circ} 17$, pp. 222, 224 y 225 , a lo que añade, significativamente: "Cierto es que algo de dolor resulta inseparable del cumplimiento de semejante obligación, en especial, cuando sea objeto de coacción”. Es exactamente lo que propugnamos en el texto.
} 
que hallar justificación todas las penas reparadoras, del mismo modo que en el daño de cada delito ellas encontrarán su naturaleza y medida.

La tarea planteada al Derecho penal del porvenir, reconstruirse de cabo a rabo según esta idea y aquel sentido, es considerable, pero también estimulante y un alivio para la mala conciencia del penalista. Aunque el desarrollo de las exigencias sistemáticas que se desprenden de la reparación requeriría un tratamiento monográfico, consignemos de momento las siguientes, a modo de conclusión: $1^{\circ}$ ) en el capítulo de la ley como única fuente inmediata del Derecho penal: interdicción absoluta de las leyes penales en blanco y, en general, las disposiciones legiferantes de la Administración ${ }^{47}$; extensión del principio de personalidad pasiva para delitos cometidos contra nacionales en el extranjero, con una restricción equivalente para el principio real en la defensa de bienes jurídicos de la sociedad indiscriminadamente considerada y del Estado; subordinación del Derecho penal por representación y la justicia penal substitutoria al requerimiento formal del ofendido por el delito; fijación del tiempo de perpetración de éste en el día de su consumación o de los actos ejecutivos que produjeron alguna lesión en el bien jurídico ${ }^{48} ; 2^{\circ}$ ) en la teoría del delito: reconfiguración del concepto de sujeto pasivo, de modo que comprenda a los animales vertebrados en casos de maltrato o muerte ${ }^{49}$, reduzca los delitos vagos o de paciente indeterminado (salvando nada más que aquellos en que sea dable identificar a un conjunto preciso de personas) y convierta los delitos «terrorista», «social» y «anarquista» en infracciones comunes susceptibles de reparación o en delitos políticos; tipificación explícita, en la Parte especial, de la comisión por omisión lesiva de bienes individuales o estatales; eliminación del resultado de peligro, real o presunto ${ }^{50}$; imputación objetiva del resultado de lesión directa o inmediatamente ligado al ámbito de protección de la norma; redacción de los tipos según acciones transitivas, de modo que no falten jamás el objeto material o el sujeto pasivo; primacía de la antijuridicidad en la estructura del delito, concebida objetivamente y cifrada en la reprobación del resultado producido, no en el «desvalor de la acción»; reconocimiento del consentimiento del interesado con efecto desincriminante en todo hecho contra bienes de titularidad individual; supresión de los privilegios en cualesquiera causas de justificación, por ejemplo, las defensas privilegiadas; mantenimiento de la culpabilidad normativa y la inculpabilidad por no exigibilidad de otra conducta; liquidación de reincidencia, habitualidad y reiteración, como también del efecto penal de la irreprochable conducta anterior y la colaboración sucesiva del reo con la Administración de Justicia; deslinde objetivo de los actos preparatorios impunes y la tentativa, con punibilidad únicamente de la tentativa que haya irrogado algún daño (tentativa acabada nociva) e impunidad absoluta de la tentativa inidónea; punición del agente provocador y de la coparticipación simulada en general, si ha perjudicado de algún modo el bien jurídico; reformulación del concurso de delitos ajustando la pena global al

\footnotetext{
${ }^{47}$ Sobre el deber jurídico de reparar no puede disponer una voluntad particular, sino la voluntad colectiva del pueblo.

${ }^{48}$ Pues antes no habrá daño alguno que reparar.

${ }^{49}$ El animal objeto del maltrato tiene una pretensión de ser restaurado, como explicaron los krausistas del siglo XIX, Krause a la cabeza, por cierto. En cambio, es absurda la penitencia divina, que los humanos emulamos neciamente con nuestra justicia animal, impuesta al navegante que asaeteó al albatros en la siniestra Balada del viejo marinero, de Samuel Taylor Coleridge.

${ }^{50}$ El peligro puede ser dejado en su sede natural, el Derecho de policía, castigándolo con sanciones administrativas, no penales.
} 
conjunto del daño causado, y $3^{\circ}$ ) en la teoría de la pena: ajuste cualitativo y cuantitativo del sistema de penas a la gravedad intrínseca del daño producido por cada grupo de delitos; prescindencia de las penas y medidas cautelares de encierro, interdicción y todas cuyo objeto jurídico no consista en una forma de reparación del mal del delito; jubilación de las penas substitutivas y los substitutivos penales; amplio catálogo de penalidades reparadoras, incluyendo las que imponen deberes familiares, de cuidado de individuos o intereses patrimoniales ajenos, trabajos y servicios personales a favor de otros, etc.; conmensuración cualitativa y cuantitativa de la penalidad según las peculiaridades del daño por restaurar material o simbólicamente; procedencia de la amnistía sólo en delitos políticos ${ }^{51}$; prescripción de todos los delitos y penas, sin causas de interrupción, pero sujeta a suspensión por actos procesales contra el inculpado o ciertos impedimentos jurídicos circunstanciales a la persecución, y compatibilidad de la pena reparadora con la indemnización civil de perjuicios ${ }^{52}$.

Estímulos y alivio para el criminalista, decíamos. Pero hay más. Es una paradoja cruel que, estando a cargo de un arte de frutos conocidamente abyectos, persistamos todavía en la convicción de que no existe otra forma de cultivarlo aparte de reducir o disimular su vileza. Viene espontánea a las mientes la figura literaria a que la mitad bondadosa del Visconte dimezzato, en la inolvidable novela de Italo Calvino, ordenaba construir máquinas "nacidas de la bondad, no de la sed de sevicias". Pues bien, al carpintero parecía imposible "hacer

\footnotetext{
${ }^{51}$ Ya que el Estado, como bien lo vio Kant, no puede disponer de los bienes de los individuos. KANT, La Metafísica de las costumbres, cit. nota $\mathrm{n}^{\circ} 30$, p. 174 (§ 49, II).

${ }^{52}$ En lo demás, la reparación es perfectamente conciliable con los principios y reglas del Derecho penal moderno, comenzando por los de legalidad, ofensividad, personalidad e igualdad, aunque su salvaguarda demanda operaciones muy cuidadosas en la técnica legislativa. Por lo pronto, la ofensa, entendida como desvalor del resultado, debe permanecer encorsetada por la presión de la tipicidad, de forma que no se extienda a resultados no comprendidos por el ámbito de protección de la norma subyacente a la figura legal. Este requerimiento repercute en el abanico de penas reparadoras, donde yacen los mayores peligros para la legalidad punitiva. Ha de ser dilatado, pero también abstracto, porque sólo pagando el precio de cierta estereotipia puede la ley evitar el terrible enemigo del arbitrio judicial, como sucedería si se comete al juez el hallazgo del género de reparación condigno al daño. Asimismo, las concepciones actuales del fundamento de la participación no verán inconveniente en que reparen también instigadores y cómplices, si es verdad que éstos intervienen con un ataque accesorio al bien jurídico. En seguida, no existe deber de reparación si los agentes tampoco obraron culpablemente, así como la personalidad de la responsabilidad penal presupone que esa obligación sea más intensa tratándose de dolo que de culpa (dicho sea de pasada, la experiencia de los acuerdos de reparación que admiten algunas legislaciones procesal penales es ilustrativa de que en los delitos culposos incluso los ofendidos directos se contentan a veces con menos, como una disculpa). Por último, la igualdad ante las penas reparadoras requerirá cláusulas salvadoras semejantes a las actuales sobre la multa, para que el sujeto repare en otra forma que la usual o, en el improbable supuesto de imposibilidad absoluta, se lo libere incluso de toda pena.

Lo que carecería de sentido en este sistema es la circunstancia atenuante legal o judicial de la reparación del daño. No así, en cambio, la llamada poena naturalis, que se debe descontar cualitativamente de la pena reparadora y hasta pudiera conducir a la prescindencia de ésta en todos los delitos, aun los más graves. La compasión, esa forma de simpatía en el dolor ajeno, el compartir el sufrimiento de nuestro prójimo, en que enraíza el efecto jurídico de la pena natural, no implica aprobar sus razones, buenas o malas, sino "negarse a considerar el sufrimiento, sea cual sea, como un hecho indiferente, y a un ser vivo, sea cual sea, como una cosa". Por eso es prima hermana de la reparación, que, contrariamente a la piedad, no pretende aumentar la cantidad de sufrimiento que ya hay en el mundo. La cita pertenece a COMTE-SPONVILLE, André, Pequeño tratado de las grandes virtudes, traducción de CORRAL, Berta, y CORRAL, Mercedes, Barcelona-Buenos Aires-México: Paidós, 2008, p. 113.
} 
Polít. crim. Vol. 12, No 24 (Diciembre 2017), Art. 10, pp. 1044-1065.

[http://www.politicacriminal.cl/Vol_12/n_24/Vol12N24A10.pdf]

funcionar de manera práctica y precisa otros artefactos que los de patíbulo y tormento", los mismos cuya manufactura pretendía el sanguinario Gramo, la otra mitad del vizconde.

Toca a la humanidad empeñarse hoy y mañana por que las imágenes paradójicas aparezcan bajo nueva luz, así sea en el pequeño y hasta ahora sombrío ruedo del Derecho penal. 
GUZMÁN, José Luis “Sentido de la pena y reparación”.

\section{BIBLIOGRAFÍA}

ALASTUEY DOBÓN, M. Carmen, La reparación de la víctima en el marco de las sanciones penales, prólogo de José Cerezo Mir, Valencia: Tirant lo Blanch, 2000.

AMBOS, Kai, MALARINO, Ezequiel, y STEINER, Christian, (Eds.), Sistema interamericano de protección de los derechos humanos y Derecho penal, 3 vols., Bogotá: Konrad Adenauer Stiftung, t. III, 2013.

ARISTÓTELES, Moral, a Nicómaco, Lima: Editorial Universo, 1967.

BAUER, Anton, Die Warnungstheorie. Nebst einer Darstellung und Beurtheilung aller Strafrechtstheorien, Göttingen: Vandenhoeck \& Ruprecht, 1830.

BELING, Ernst von, Die Vergeltungsidee und ihre Bedeutung für das Strafrecht, Aalen: Scientia Verlag, 1978 (reimpresión de la edición de Leipzig, 1908).

BETTIOL, Giuseppe, El problema penal, traducción de GUZMÁN DALBORA, José Luis, y prólogo de Manuel de Rivacoba y Rivacoba, Buenos Aires: Hammurabi, 1995.

BETTIOL, Giuseppe, y PETTOELlO MANTOVANI, Luciano, Diritto penale. Parte generale, Dodicesima edizione riveduta e integrata, Padova: Cedam, 1986.

BINDING, Karl, Compendio di Diritto penale. Parte generale, prefazione, note e traduzione sulla ottava edizione tedesca di BORETTINI, Adelmo; Roma: Athenaeum, 1927.

, Die Normen und ihre Übertretung. Eine Untersuchung über die rechtsmässige Handlung und die Arten des Delikts, 4 vols., Leipzig: Verlag von Wilhelm Engelmann, t, I, 1872.

CARRARA, Francesco, Programma del corso di diritto criminale. Del delitto, della pena, Bologna: Il Mulino, 1993.

CATTANEO, Mario A., Pena, diritto e dignità umana. Saggio sulla filosofía del diritto penale, ristampa aggiornata, Torino: Giappichelli Editore, 1998.

COMTE-SPONVILLE, André, Pequeño tratado de las grandes virtudes, traducción de CORRAL, Berta, y CORRAL, Mercedes, Barcelona.Buenos Aires- México: Paidós, 2008.

CORREA, Cristián, en: STEINER, Christian, y URIBE, Patricia, (Eds.), Convención americana sobre derechos humanos. Comentario, Bogotá: Konrad Adenauer Stiftung, 2014, pp. 817-888.

DILTHEY, Guillermo, La esencia de la Filosofía, con un Estudio preliminar de Eugenio Pucciarelli, traducción de TABERNIG, Elsa; Buenos Aires: Editorial Losada, 1944.

DORADO MONTERO, Pedro, El Derecho protector de los criminales, 2 vols., Pamplona: Analecta, 1999.

DUFF, Anthony, Sobre el castigo. Por una justicia penal que hable el lenguaje de la comunidad, traducción de PONS, Horacio, revisada por ROTH, Laura; Buenos Aires: Siglo Veintiuno Editores, 2015.

FERRAJOLI, Luigi, Diritto e ragione. Teoria del garantismo penale, prefazione di Norberto Bobbio, Roma-Bari: Editori Laterza, 1989.

GALAIN PALERMO, Pablo, Justicia restaurativa y sistema penal. ¿Cambio de paradigma o nuevas herramientas de la justicia penal?, Montevideo: Universidad Católica del Uruguay, 2016. 2010.

GARCÍA MÁYNEZ, Eduardo, Introducción al estudio del Derecho, México: Porrúa, $48^{a}$ ed., 1996. 
GARCÍA-PABLOS DE MOLINA, Antonio, Introducción al Derecho penal, Madrid: Editorial Universitaria Ramón Areces, $3^{\text {a }}$ ed., 2005.

GUZMÁN DALBORA, José Luis, "La «individualización» de la pena: contenido, trayectoria histórica y crítica del concepto", Revista de Ciencias Sociales, Facultad de Derecho y Ciencias Sociales de la Universidad de Valparaíso, Nº 56 (2010), pp. 113 134.

HEGEL, Guillermo Federico, Filosofía del Derecho, introducción de Carlos Marx, traducción de MENDOZA DE MONTERO, Angélica; Buenos Aires: Editorial Claridad, 1955.

HIRSCH, Hans Joachim, "La posición del ofendido en el Derecho penal y en el Derecho procesal penal, con especial referencia a la reparación", traducción de SÁNCHEZ OCAÑA, Roberto, Cuadernos de Política Criminal, de Madrid, № 42 (1980), pp. 561-575.

JAKOBS, Günther, Bases para una teoría funcional del Derecho penal, Lima: Palestra Editores, 2000.

, La pena estatal: significado y finalidad, traducción de CANCIO MELIÁ, Manuel, y FEIJOO SÁNCHEZ, Bernardo; Navarra: Aranzadi, 2006.

JIMÉNEZ DE ASÚA, Luis, Tratado de Derecho penal, publicados, 7 vols., Buenos Aires: Editorial Losada, t. II, $2^{a}$ ed., 1950.

KANT, Immanuel, La metafísica de las costumbres, estudio preliminar de Adela Cortina Orts, traducción y notas de CORTINA ORTS, Adela, y CONILL SANCHO, Jesús; Madrid: Tecnos, 1989.

Obras selectas. Crítica de la razón pura y Crítica de la razón práctica, traducción de FERNÁNDEZ NÚÑEZ, Manuel, MIÑANA y VILLAGRAÑA, E., y GARCÍA MORENTE, Manuel, Buenos Aires: El Ateneo, 2a ed., 1961

KINDHÄUSER, Urs, y MAÑALCH, Juan Pablo, Pena y culpabilidad en el Estado democrático de Derecho, Montevideo-Buenos Aires: Editorial B. de F., 2011.

KLUG, Ulrich, "Despedida de Kant y Hegel. (Una crítica filosófica básica)", en: EL MISMO, Problemas de la Filosofía y de la pragmática del Derecho, traducción de SEÑA, Jorge M., México: Fontanamara, 2002, págs. 31-36.

LÓPEZ DE OÑATE, Flavio, La certeza del diritto, nuova edizione riveduta, a cura di Guido Astuti, Milano: Giuffrè, 1968.

MAYER, Max Ernst, Derecho penal. Parte general, traducción de POLITOFF LIFSCHITZ, Sergio, con revisión general y prólogo de GUZMÁN DALBORA, José Luis, Montevideo-Buenos Aires: Editorial B. de F., 2007.

, Filosofía del Derecho, traducción de la $2^{\mathrm{a}}$ edición original por LEGAZ LACAMBRA, Luis, Barcelona: Editorial Labor, 1937.

MILLAS JIMÉNEZ, Jorge, Filosofía del Derecho, estudio preliminar, notas y edición de Juan O. Cofré, Santiago de Chile: Ediciones Universidad Diego Portales, 2012.

NAGLER, Johannes, Die Strafe. Eine juristische-empirische Untersuchung, Aalen: Scientia Verlag, 1970 (reimpresión de la edición de Leipzig, 1918).

RADBRUCH, Gustav, Filosofía del Derecho, traducción de MEDINA ECHAVARRÍA, José, Madrid: Editorial Revista de Derecho Privado, $3^{\text {a }}$ ed., 1952.

, "El problema de la idea del Derecho", en: EL MISMO, Tres estudios de Filosofía del Derecho y una arenga para los jóvenes juristas, traducción, 
introducción y notas de GUZMÁN DALBORA, José Luis, Montevideo-Buenos Aires: Editorial B. de F., 2013, pp. 59-69.

Introducción a la Filosofía del Derecho, traducción de ROCES, Wenceslao, México: Fondo de Cultura Económica, 1985.

, "La idea educativa en el Derecho penal", en: EL MISMO, El hombre en el Derecho. Conferencias y artículos seleccionados sobre cuestiones fundamentales del Derecho, traducción de DEL CAMPO, Aníbal, Buenos Aires: Depalma, 1980.

RIVACOBA Y RIVACOBA, Manuel de, Función y aplicación de la pena, Buenos Aires: Depalma, 1993.

RODRÍGUEZ DEVESA, José María, Derecho penal español. Parte general, decimotercera edición revisada y puesta al día por Alfonso Serrano Gómez, Madrid: Dykinson, 1990.

ROBINSON, Paul, Principios distributivos del Derecho penal. A quién debe sancionarse y en qué medida, traducción e introducción de CANCIO MELIÁ, Manuel y ORTIZ DE URBINA, Íñigo, Madrid: Marcial Pons, 2012.

RÖDER, Carlos David Augusto, Las doctrinas fundamentales reinantes sobre el delito y la pena en sus interiores contradicciones, traducción de GINER, Francisco, Pamplona: Analecta, 1999 (edición facsimilar de la de Victoriano Suárez, Madrid, 1876).

ROXIN, Claus, Derecho penal. Parte general, t. I. (Fundamentos. La estructura de la teoría del delito), traducción de la $2^{\mathrm{a}}$ ed. alemana y notas por LUZÓN PEÑA, DiegoManuel, DÍAZ Y GARCÍA CONLLEDO, Miguel, y VICENTE REMESAL, Javier de, Madrid: Editorial Cívitas, 1997.

SBRICCOLI, Mario, Crimen laesa maiestatis. Il problema del reato político alle soglie della scienza política moderna, Milano: Giuffrè, 1974.

SCHLEGEL, Friedrich, $O$ dialeto dos fragmentos, tradução, apresentação e notas de SUZUKI, Márcio, São Paulo: Iluminuras, 1997.

SÉNECA, Lucio, "Sobre la ira", en: EL MISMO, Tratados filosóficos, tragedias, epístolas morales, prólogo de José María Pemán y traducción de AZAGRA, J., Madrid: EDAF, 1964, pp. 331-500.

VECCHIO, Giorgio del, "Sobre el fundamento de la justicia penal", Apéndice de su libro La justicia, traducción de LAPLAZA, Francisco P., Buenos Aires: Editorial Depalma, 1952.

ZAFFARONI, Eugenio Raúl, “¿Derecho penal humano o inhumano?”, Revista de Derecho penal y Criminología, de Buenos Aires, año IV, Nº 8 (2014), pp. 3-15.

, con la colaboración de Alagia, Alejandro, y Slokar, Alejandro, Derecho penal. Parte general, Buenos Aires: Ediar, $2^{\mathrm{a}}$ ed., 2002. 